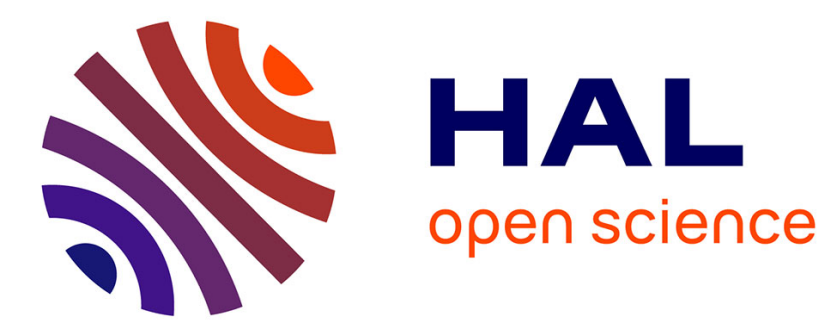

\title{
Microfiltration of sodium caseinate on ceramic membranes
}

\author{
Marie-Hélène Famelart, O. Surel
}

\section{To cite this version:}

Marie-Hélène Famelart, O. Surel. Microfiltration of sodium caseinate on ceramic membranes. 2nd International Conference on Inorganic Membranes, Jul 1991, Montpellier, France. hal-02244981

\section{HAL Id: hal-02244981 \\ https://hal.science/hal-02244981}

Submitted on 7 Jun 2020

HAL is a multi-disciplinary open access archive for the deposit and dissemination of scientific research documents, whether they are published or not. The documents may come from teaching and research institutions in France or abroad, or from public or private research centers.
L'archive ouverte pluridisciplinaire HAL, est destinée au dépôt et à la diffusion de documents scientifiques de niveau recherche, publiés ou non, émanant des établissements d'enseignement et de recherche français ou étrangers, des laboratoires publics ou privés. 
PROCEEDINGS AT THE SECOND INTERNATIONAL CONFERENCE ON INORGANIC MEMBRANES

, 1991, MONTPELLIER.

MICROFILTRATION, CERAMIC MEMBRANES, BETA CASEIN, EXTRACTION

\title{
MICROFILTRATION OF SODIUM CASEINATE ON CERAMIC MEMBRANES*
}

\author{
O. Surel \\ M.H. Famelart \\ SCT-Alcoa B.P.1 65460 Bazet cedex \\ INRA 65 rue de st Brieuc Rennes cedex
}

\begin{abstract}
Low temperature microfiltration of $\mathrm{Na}$ caseinate, in order to extract beta casein, has been studied on ceramic Membralox membranes. Tangential flow velocity, membrane pore diameter and calcium concentration effects were investigated. The results show that increasing calcium concentration from 0 to $1{\mathrm{~g} . \mathrm{I}^{-1}}^{-1}$ induces a decrease in permeation rate, while further addition does not modify it. At the same time beta casein transmission rate is negatively affected by calcium adding. Furthermore, 2 hour experiments clearly proved that hydraulic backflush can stabilize fluxes. The main result of the study is that $0.1 \mu \mathrm{m}$ Membralox membrane is beta casein specific, and that microfiltration of $\mathrm{Na}$ caseinate without calcium leads to a $20 \mathrm{~g} \cdot \mathrm{h}^{-1} \cdot \mathrm{m}^{-2}$ productivity of beta casein.
\end{abstract}

\section{INTRODUCTION}

Beta casein content of bovine milk is about 9 to $11 \mathrm{g.t}-1$ which accounts for 34 to $38 \%$ of total caseins (1). It is the most hydrophobic of all the caseins and moreover, the highly charged domain is clearly separate from the large hydrophobic domain (2). This amphoteric structure leads to consider beta casein as a surface active agent (3). Furthermore, physiological properties of its constitutive peptides are associated with various physiological functions (4). Thus, an extraction and purification procedure of beta casein has a scientific but also an industrial significance. In this context, the INRA patented in 1986 an extraction process of beta casein using low temperature microfiltration of sodium caseinate (5). The aim of the present study was to test new Membralox microfiltration membranes according to INRA's patent conditions. 


\section{MATERIAL AND METHODS}

Microfiltration of $2 \% \mathrm{Na}$ caselnate (Armor protelnes, France) at $5^{\circ} \mathrm{C}$ was studied on a $0.2 \mathrm{~m}^{2}$ filtration plant fitted with a hydraulic defouling backflush device (SCT-Alcoa, France). Two different Membralox membranes were tested, w1th 0.1 or $0.2 \mu \mathrm{m}$ pore diameter. During one experiment we tested successively 3 couples of flow velocity (V) / transmembrane pressure (TMP) (4 $\mathrm{m} . \mathrm{s}^{-1} / 0.95$ bar, $6 \mathrm{~m} . \mathrm{s}^{-1} / 1.4$ bar, $7.3 \mathrm{~m} . \mathrm{s}^{-1} / 1.9$ bar ), and the addition of calcium with Cacl2 from 0 to $3 \mathrm{g.i}-1$. Casein concentration in the permeate and the retentate were measured with a FPLC (Pharmacia, Sweden) apparatus according to Andrews et al. (6).

\section{RESULTS AND DISCUSSION}

Flux

Either $0.1 \mu \mathrm{m}$ or $0.2 \mu \mathrm{m}$ membrane presented a similar behaviour during our experiments. Fluxes are quite identical, and stable (table 1 ). In both cases, calclum adding from 0 to 1 g. $1^{-1}$ induces a decline in flux ( $f i g .1$ ) while further addition does not modify it.

\begin{tabular}{|ccc|}
\hline Flux (I.h-1.m-2) & \multicolumn{2}{c|}{ calcium (g.l-1) } \\
& 0 & 1 \\
\hline $0.2 \mu \mathrm{m}$ membrane & $54 \pm 8$ & $27 \pm 4$ \\
$0.1 \mu \mathrm{m}$ membrane & $54 \pm 4$ & $31 \pm 3$ \\
\hline
\end{tabular}

TABLE 1: FLUX STABILITY FOR 2 HOURS

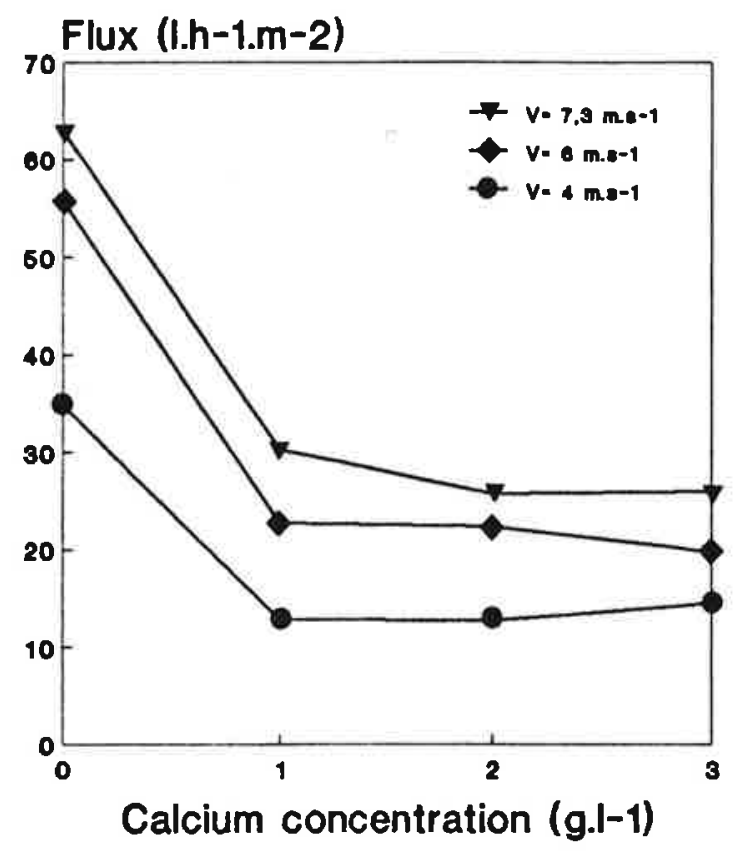

FIG.1: EFFECT OF CALCIUM ON FLUX

\section{Protein concentration in the filtrate}

$0.1 \mu \mathrm{m}$ membrane shows a good separation ( $\mathrm{f} 1 \mathrm{~g} .2$ ) of beta casein (alpha $S$ casein concentration in the filtrate keeps negligible). Particle diameters in the product without calcium is about $20 \mathrm{~nm}(7)$, which explain partial retention of all types of casein $(8,9)$. 
Furthermore, interactions occurring between protein and membrane could be regarded as a part of explanation. Electrical charge of casein at $\mathrm{pH} 6.8$ is negative (10) and $0.1 \mu \mathrm{m}$ membrane has a $\mathrm{ZrO}_{2}$ filtration layer which is negatively charged at this $\mathrm{pH}$ (11). Thus electrostatic repulsions could also explain the retention of soluble casein.

Increasing calcium concentration leads to a decrease of beta casein concentration in the filtrate ( $f 1 g .2$ ) which could be explained by a decrease in its solubilization. On one hand, the $\mathrm{CaCl}_{2}$ modifies ionic strength in the aqueous phase which is defavorable to beta casein solubilization $(12,13)$. On the other hand, colloidal suspension of submicelles becomes a suspension of micelles mainly composed of alpha $S$ casein when calcium is added $(14,15)$; since beta casein is a little calcium sensitive (15), it may be incorporated into the micelles. Thus soluble beta casein quantity can decrease.
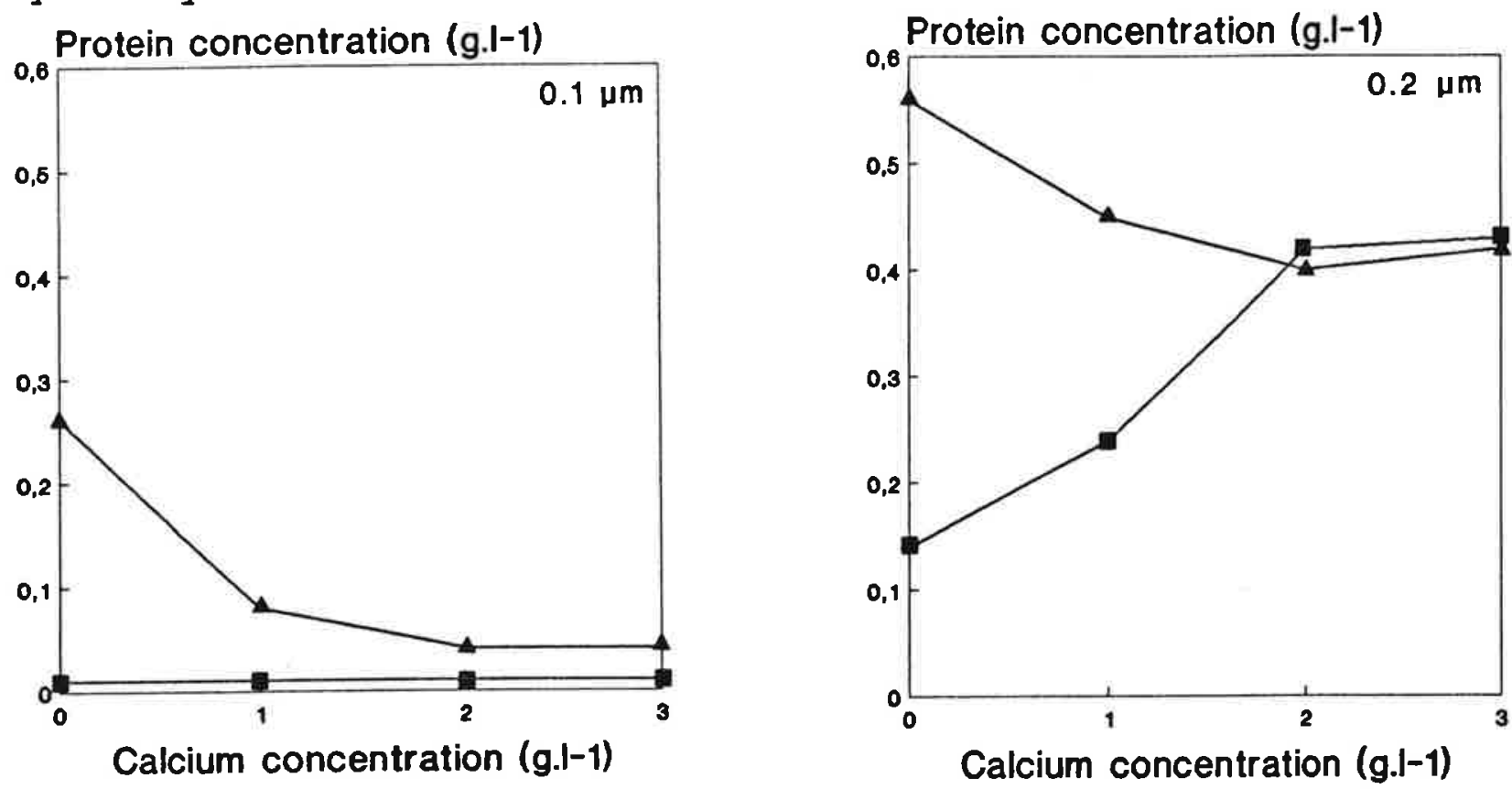

FIG.2: EFFECT OF CALCIUM ON 0.1 AND $0.2 \mu \mathrm{m}$ MEMBRANE FILTRATE COMPOSITION

\section{ALPHA S CASEIN}

\section{- BETA CASEIN}

V. $7.3 \mathrm{~m} . \mathrm{s}-1$

TMP= 1.9 bar

The $0.2 \mu \mathrm{m}$ alumina membrane behavour is different (fig.2) When calcium is added, there is a decrease in beta casein solubilization in the same way as previously, but alpha $S$ casein agregates seem to be transmitted through the membrane. Dalgleish (16) measured particle diameters of $200 \mathrm{~nm}$ formed from spray dried caseinate in $0.6 \mathrm{~g} . \mathrm{I}^{-1}$ calcium solution. Such agregates could be transmitted through $0.2 \mu \mathrm{m}$ membrane. In that case particle size could be a part of explanation, but furthermore, because of $\mathrm{Al}_{2} \mathrm{O}_{3}$ positive surface potential there is no repulsion between casein and filtration layer. 


\section{CONCLUSIONS}

This study points out the high beta casein specificity of $0.1 \mu \mathrm{m}$ membrane which leads to a beta casein productivity of 20 g.h-1.m-2. Beta casein purity according to Andrews' FPLC method (6) is acceptable, and preliminary assays showed that it is possible to eliminate some contaminating proteins from the microfiltrate using ultrafiltration. From a biochemical point of view, best results are obtained without calcium added. The effect of calcium ions on $0.2 \mu \mathrm{m}$ membrane permeation rate and protein retention is not totally understood, because we lack information on $\mathrm{Na}$ caseinate physico-chemical properties (particle size and zeta potential). These parameters will be investigated.

$\star$

Work supported by SCT-Alcoa

1) Cheftel,C., Cuq,J.L., Lorient,D.: in "Proteines alimentaires" Lavoisier ed. Paris, 1986

2) Swaisgood,H.E.:in "Fundamentals in dairy chemistry" P.F. Fox ed. Appl. Sci. ed. London, 1982

3) Payens, T.A.: : Lait, 1982,62, 306

4) Maubois, J.L., Leonil, J.: Lait, 1989,69, 245

5) Terre, E., Maubols, J.L., Brulé,G. Pierre A.: French patent $N^{\circ} 8600325,1986$

6) Andrews, A. T. , Taylor, M. B . , Owen, P. J. : J.Chromatogr . , 1985, 348, 177

7) Walstra, P.:J. Dairy Sci.,1990,73,1965

8) Aimar, P., Meireles, M., Sanchez, V.:J.Membr.Sc1 ., 1990, 54, 321

9) Jourdan M.F.,Milisic, V.:Proc.Vth.World Filtr.Congr $, 1990,15$

10) Dalgleish, D.G.:J. Dairy Res., 1985, 51,425

11) Private commun.

12) Murphy, J.M., Fox P.F.: Food Chem., 1991,39, 27

13) Famelart, M.H. , Hardy, C., Brule G.: Lait, 1989, 69, 47

14 ) Baumy, J.J. , Brulé, G.: Lait, 1986,66,65

15) Dalgleish, D.G.:J.Soc.Da1ry Technol., 1989,42,91

16) Dalgleish,D.G., Law, J.R.: J. Soc. Dairy Technol . , 1988, 41, 1 